\title{
E-Marketing Applications Based On Virtual Reality Using Sostac Planning Method On Sales Property
}

\author{
Philip Kristy Wijaya ${ }^{1}$, Aditiya Hermawan ${ }^{2}$ \\ ${ }^{1}$ Universitas Buddhi Dharma, Teknik Informatika, Banten, Indonesia \\ ${ }^{2}$ Universitas Buddhi Dharma, Teknik Informatika, Banten, Indonesia
}

\begin{tabular}{l}
\hline SUBMISSION TRACK \\
\hline Received : February 1, 2018 \\
Final Revision: February 6, 2018 \\
Available Online: February 27, 2018 \\
KEY WORD \\
\hline Virtual Reality, Website, SOSTAC, E- \\
Marketing, Properti \\
CORRESPONDENCE \\
\hline
\end{tabular}

Phone: +6287-808-777-515

E-mail: philipkristy21@gmail.com

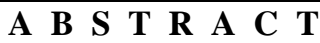

Increased demand for property in Indonesian society, opening up a great opportunity for entrepreneurs to start a business in the property sector. The large number of new entrepreneurs, opening up many different ways of offering attractive products and promos that bring the impact of significant sales decline for those who can not compete. One such problemsolving proposal is to analyze current conditions and create new, powerful goals and strategies to implement. The methods that can serve as guidelines in the analysis and planning of the marketing strategy are SOSTAC (Situation Analysis, Objectives Setting, Strategy, Tactics, Action and Control). Based on the results of SOSTAC analysis and suggestions the way that can be done is to build E-Marketing with media websites that can be easily reached by the public and a marketing tool for marketing executive. On the website created a Virtual Reality feature that can display the form of building to consumers to increase consumer confidence in purchasing units. Based on testing and evaluation by consumers a new marketing strategy plan is worth trying and applied in marketing strategy.
\end{abstract}

\section{INTRODUCTION}

Along with the increasing number of population in Indonesia, the more number of entrepreneurs or investors in the country and abroad who glance at the sector of property development in Indonesia. These business actors (or so-called developers) offer a variety of offers. Starting from a varied price, strategic location and also the shape and appearance of buildings made in such a way as to win the hearts of potential buyers.
Obtained survey data from the website www.bi.go.id, that the index of commercial property supply in Indonesia in the third quarter of 2016 reached 106.65 or increased by $0.48 \%$ which is higher than the previous quarter which only reached $0.28 \%$. Demand for commercial property during the quarter was recorded at 128.20 , which increased by $0.46 \%$ from the previous quarter's $0.28 \%$. If seen in the fourth quarter, the index of commercial property supply in Indonesia in 2016 reached 107.29 or increased by $0.60 \%$ 
which is higher than the previous quarter which only reached $0.48 \%$. Demand for commercial property during the quarter was recorded at 128.71 , an increase of $0.39 \%$ over the previous quarter.

Virtual Reality consists of two words, namely virtual and reality which means virtual and reality. Virtual Reality is a technology that can interact with an environment simulated by a computer. In reality, virtual reality is used to describe the three-dimensional environment generated by computers and can interact with []). In other words, the user can view the creation of an environment without necessarily coming directly to the environment. With this technology, bringing a new way for developers to market their products for sale. Potential buyers can preview the concept and model of the property product so they feel interested in making a purchase.

In addition to the presence of Virtual Reality technology, the property developers must also be careful in choosing and using the method of planning to determine the marketing strategy. One of the methods that can be used is SOSTAC (Situation Analysis, Objective Setting, Strategy Formulation, Tatics, Action, and Control). SOSTAC is a model of planning framework that can be easily followed, yet it is able to identify all the major things that must be done to achieve the goal (Chaffey, 2009: 418). Using this method, property developers can develop and plan their marketing strategies more closely, effectively and efficiently.

With the use of Virtual Reality technology and planning with SOSTAC method is expected to increase public awareness about the brand of the products sold, so as to improve the rating of the company in the middle of the community or amid competition with other developers, which will indirectly affect the arrival of prospective customers and increase in the number of product sales so as to achieve the expected target.

\section{Method}

\section{SOSTAC Method}

SOSTAC is a model planning framework that can be easily followed, but is able to identify all the main things that must be done to achieve the goal. The stages in this method are as follows:

\section{a. Situation Analysis}

Situation analysis is divided into 3, namely: Demand Analysis, Competitor Analysis and SWOT Analysis (Strengths, Weaknesses, Opportunities, Threats). At the Demand Analysis stage, the authors will distribute questionnaires to the respondents (the general public and consumers) about brand awareness, the marketing strategy weakness of the developer and the demand of the respondents.

At Competitor Analysis stage, the author will take some other competitor website website and make comparisons (advantages and disadvantages).

At the SWOT Analysis stage, the author will analyze strategic issues on Strengths, Weaknesses, Opportunities and Threats. After obtaining the data, it will be further developed into the most influential (internal and external) issues of combinations.

\section{b. Objectives Setting}

Objectives are key elements of the process strategy model. Companies need a foundation to help to achieve the desired goals. One of the guides we can use to create specific, measurable and realistic goals is 5S (Sell, Serve, Speak, Save and Sizzle).

\section{c. Strategy Formulation}

The strategy to be created should focus on the goals that have been made before. The e-marketing strategy is a long-term phase that defines the developments needed to achieve the stated goals.

\section{d. Tactics}

Once the strategy has been developed as part of e-marketing planning, tactics must be implemented to achieve these strategies. 


\section{e. Action}

It is the final component in e-marketing planning that describes the activities to be performed, in accordance with the strategies and tactics, ready to be applied in carrying out the plan. At this stage the author will make Use Case Diagrams, Activity Diagrams, Sequence Diagrams and Entity Relationship Diagram. For programming, the author will use Unity and Google Sketch Up applications. In the preparation of the database, the author will use XAMPP with MySQL programming language and PHP.

\section{f. Control}

This stage aims to monitor the views of customers and opinions. The control stage is done by periodically evaluating whether the e-marketing application that has been implemented has reached the stated goal yet. One method that can be done to run the control function is to perform blackbox testing. In addition, the authors will also conduct surveys to some respondents (the general public and consumers) about the assessment of the applications that have been made, the next will be known advantages and disadvantages of the application to become a reference stage of further development.

Table 1 SOSTAC Dimensions

\begin{tabular}{|c|c|l|}
\hline Phase & Planning & Answer the Question \\
\hline $\mathbf{S}$ & Situation & $\begin{array}{l}\text { Where the current } \\
\text { position }\end{array}$ \\
\hline $\mathbf{O}$ & Objectives & $\begin{array}{l}\text { At the position and } \\
\text { condition where desired }\end{array}$ \\
\hline $\mathbf{S}$ & Strategy & $\begin{array}{l}\text { How to reach that } \\
\text { position (in general) }\end{array}$ \\
\hline $\mathbf{T}$ & Tactics & $\begin{array}{l}\text { How do we achieve that } \\
\text { the goal) (in more } \\
\text { detail and technically) }\end{array}$ \\
\hline $\mathbf{A}$ & Action & $\begin{array}{l}\text { What specific actions } \\
\text { are required in tactics } \\
\text { per step and how to } \\
\text { achieve that }\end{array}$ \\
\hline $\mathbf{C}$ & Control & $\begin{array}{l}\text { How do we know can } \\
\text { get there }\end{array}$ \\
\hline
\end{tabular}

\section{RESULT}

The data used by the researchers through the survey by distributing questionnaires to 15 respondents, then in the analysis and made a plan based on SOSTAC is divided into several sections:

\section{Situation Analysis}

Table 2 Brand Awareness of Company Properties

\begin{tabular}{|c|l|c|}
\hline No & \multicolumn{1}{|c|}{ Information } & $\begin{array}{c}\text { Number of } \\
\text { Respondents }\end{array}$ \\
\hline 1 & Already Knowing Property & 3 people \\
\hline 2 & Not Knowing Property & 12 people \\
\hline \multicolumn{2}{|c|}{ TOTAL Responden } & $\mathbf{1 5}$ people \\
\hline
\end{tabular}

Table 3 Weakness of Promotion Strategy PT. Ligamas Sejahtera

\begin{tabular}{|c|l|c|}
\hline No & \multicolumn{1}{|c|}{ Weakness } & $\begin{array}{c}\text { Number of } \\
\text { Respondents }\end{array}$ \\
\hline 1 & $\begin{array}{l}\text { The lack of promos is } \\
\text { interesting }\end{array}$ & 3 people \\
\hline 2 & $\begin{array}{l}\text { Can not see condition of } \\
\text { building being sold (no } \\
\text { sample house) }\end{array}$ & 3 people \\
\hline 3 & $\begin{array}{l}\text { Less promotion on main } \\
\text { roads }\end{array}$ & 2 people \\
\hline 4 & No website & 1 people \\
\hline 5 & Not familiar on the internet & 1 people \\
\hline 6 & $\begin{array}{l}\text { Lack of quality service } \\
\text { from sales }\end{array}$ & 1 people \\
\hline
\end{tabular}

Tabel 4 Permintaan Strategi Promosi Pengembang Properti Saat Ini

\begin{tabular}{|c|l|c|}
\hline No & \multicolumn{1}{|c|}{ Respondent's Request } & $\begin{array}{c}\text { Number of } \\
\text { Respondents }\end{array}$ \\
\hline 1 & $\begin{array}{l}\text { There is a display of } \\
\text { building products being } \\
\text { sold }\end{array}$ & 7 people \\
\hline 2 & $\begin{array}{l}\text { Easy to contact sales } \\
\text { executive (easy to get } \\
\text { information about product) }\end{array}$ & 6 people \\
\hline 3 & $\begin{array}{l}\text { Have a project or company } \\
\text { website }\end{array}$ & 5 people \\
\hline 4 & $\begin{array}{l}\text { Provide great discount } \\
\text { promos }\end{array}$ & 4 people \\
\hline 5 & Provide interesting promos & 3 people \\
\hline 6 & Ease of making payments & 3 people \\
\hline 7 & $\begin{array}{l}\text { Can be searched on the } \\
\text { internet }\end{array}$ & 2 people \\
\hline 8 & $\begin{array}{l}\text { Easy to administer } \\
\text { administratively }\end{array}$ & 2 people \\
\hline 9 & $\begin{array}{l}\text { Installed on the property } \\
\text { search site }\end{array}$ & 1 people \\
\hline 10 & $\begin{array}{l}\text { Provide true and honest } \\
\text { information }\end{array}$ & 1 people \\
\hline 11 & It's on the top list on google & 1 people \\
\hline
\end{tabular}




\section{User Requirement}

User Requirement uses the data that has been obtained from the distribution of questionnaires to 15 respondents about what is desired by the respondent to manufacture the application to be built.

Table 5 User Requirement

\begin{tabular}{|c|l|}
\hline No & \multicolumn{1}{|c|}{ I want this app to be } \\
\hline 1 & It has an interesting look \\
\hline 2 & Displays complete product information \\
\hline 3 & $\begin{array}{l}\text { Can display the virtual reality product } \\
\text { building }\end{array}$ \\
\hline 4 & $\begin{array}{l}\text { Can display videos and images (both } \\
\text { perspectives and original images) }\end{array}$ \\
\hline 5 & There is a feature to download product flyer \\
\hline 6 & $\begin{array}{l}\text { Have a menu to display the latest promotions } \\
\text { and news }\end{array}$ \\
\hline 7 & $\begin{array}{l}\text { Can provide information on latest property } \\
\text { developments }\end{array}$ \\
\hline 8 & Have a menu to contact the sales executive \\
\hline 9 & There is a backsound on the website \\
\hline 10 & Can display the project master plan \\
\hline 11 & Can display a map of the project location \\
\hline 12 & Has a menu that can display job openings \\
\hline
\end{tabular}

\section{Objectives Setting and Strategy} Formulation

The following table Objectives (Objectives Setting) and Strategy Formulation (Strategy Formulation) promotional activities to be performed on the design of this application:

Tabel 6 Objectives Setting dan Strategy Formulation

\begin{tabular}{|c|c|c|}
\hline $\begin{array}{l}\mathrm{N} \\
\mathrm{O}\end{array}$ & Objectives Setting & Strategy Formulation \\
\hline 1 & $\begin{array}{l}\text { Create a website } \\
\text { media that can be } \\
\text { accessed online by } \\
\text { the community } \\
\text { anywhere, } \\
\text { anytime and by } \\
\text { anyone. }\end{array}$ & 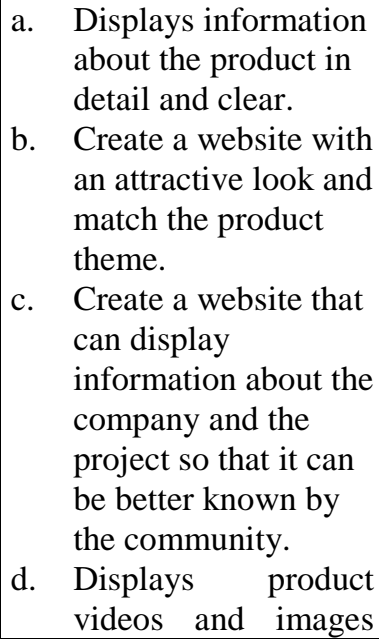 \\
\hline
\end{tabular}

\begin{tabular}{|c|c|c|}
\hline & & $\begin{array}{l}\text { and } \\
\text { environment. }\end{array}$ \\
\hline 2 & $\begin{array}{l}\text { Create a media } \\
\text { that can display } \\
\text { the form of } \\
\text { building products } \\
\text { sold, so that } \\
\text { consumers have a } \\
\text { first view of the } \\
\text { product to be } \\
\text { purchased that can } \\
\text { increase the } \\
\text { attractiveness of } \\
\text { arrival even make } \\
\text { a purchase. }\end{array}$ & $\begin{array}{l}\text { a. Creating a virtual } \\
\text { reality feature that } \\
\text { can be used by the } \\
\text { community and } \\
\text { display the building } \\
\text { form of the product } \\
\text { and can be displayed } \\
\text { on the company } \\
\text { website. }\end{array}$ \\
\hline 3 & $\begin{array}{l}\text { Increase and } \\
\text { extend the reach } \\
\text { of consumer brand } \\
\text { awareness. }\end{array}$ & 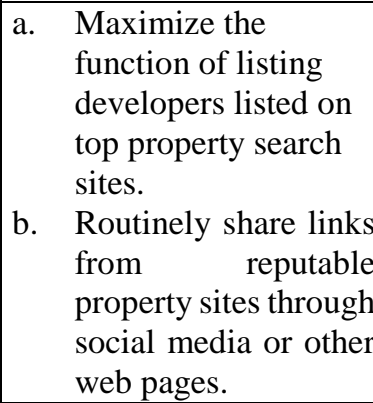 \\
\hline 4 & $\begin{array}{l}\text { Create a media } \\
\text { that can deliver } \\
\text { promos and latest } \\
\text { news about the } \\
\text { product, so the } \\
\text { deployment } \\
\text { process becomes } \\
\text { faster, wide range } \\
\text { and right on target. }\end{array}$ & \begin{tabular}{|l} 
a. Displays promos, \\
news and articles on \\
the website page, so \\
it can be accessed \\
online and by people \\
who are looking for \\
property. \\
b. Regularly distribute \\
promo links and news \\
contained in the \\
pages of the website \\
through social media \\
or other website \\
pages.
\end{tabular} \\
\hline 5 & $\begin{array}{l}\text { Improve the } \\
\text { quality of good } \\
\text { service and } \\
\text { professional. }\end{array}$ & $\begin{array}{l}\text { a. Create a medium that } \\
\text { can be used by } \\
\text { people to ask } \\
\text { questions, ask for } \\
\text { more information or } \\
\text { provide criticism and } \\
\text { suggestions. } \\
\text { b. Create a media that } \\
\text { can display } \\
\text { information to } \\
\text { improve the quality } \\
\text { of service in terms of } \\
\text { internal company. }\end{array}$ \\
\hline
\end{tabular}

\section{Tactics}

The following table Tactics (Tactics) promotional activities to be performed on the 
design of this application based on points on Objectives Setting and Strategy Formulation:

Table 7 Tactics

\begin{tabular}{|c|c|}
\hline $\begin{array}{c}\text { Form } \\
\text { ulati } \\
\text { on }\end{array}$ & Tactics \\
\hline $1 \mathrm{a}$ & $\begin{array}{l}\text { 1. On the website will be made menu, } \\
\text { namely: } \\
\text { a. "Product", the menu used to display } \\
\text { all information about the marketed } \\
\text { product (in this paper there are two } \\
\text { sub-menus, namely: "Housing" and } \\
\text { "Business Area"). The information } \\
\text { submitted will be elaborated in } \\
\text { detail, including: } \\
\text { i. Image Perspective. } \\
\text { ii. Image Original Product (if the } \\
\text { unit already exists that ready } \\
\text { stock). } \\
\text { iii. Basic information about the } \\
\text { product (building type, land } \\
\text { area, building area, electric } \\
\text { power, water type, house face } \\
\text { and carport). } \\
\text { iv. Product building specifications. } \\
\text { v. Views of buildings in Virtual } \\
\text { Reality. } \\
\text { b. "Facility", in this menu will display } \\
\text { detail information (pictures, basic } \\
\text { information) about all facilities that } \\
\text { exist in the project of the product. } \\
\text { This menu has sub-menus, they are: } \\
\text { i. "Sport Club" which contains } \\
\text { information on: swimming } \\
\text { pool, fitness center and table } \\
\text { tennis. } \\
\text { ii. "Jogging Track". } \\
\text { iii. "Boom Gate" which contains } \\
\text { information about the security of } \\
24 \text { hours are: CCTV and } \\
\text { security officers. }\end{array}$ \\
\hline $1 b$ & $\begin{array}{l}\text { 1. Website will be made with simple- } \\
\text { modern concept. Views of the website } \\
\text { will be more decorated with green } \\
\text { color, in accordance with the theme of } \\
\text { products that are beautiful and united } \\
\text { with nature. }\end{array}$ \\
\hline $1 \mathrm{c}$ & $\begin{array}{l}\text { 1. Will be made menu "About Us", on this } \\
\text { menu will be displayed detailed } \\
\text { information about company profile. }\end{array}$ \\
\hline $1 d$ & $\begin{array}{l}\text { 1. In the "Products" menu, each sub- } \\
\text { menu will display the project image } \\
\text { (perspective and original) which can } \\
\text { be changed by clicking left or right } \\
\text { (slides). } \\
\text { 2. In the "Products" menu, each sub- } \\
\text { menu will display a video (if any) }\end{array}$ \\
\hline
\end{tabular}

\begin{tabular}{|c|c|}
\hline & $\begin{array}{l}\text { taken link from youtube (on the right } \\
\text { side of the page). } \\
\text { 3. In the "Facilities" menu, will display a } \\
\text { picture of the entire facility and the } \\
\text { view of the project environment. }\end{array}$ \\
\hline $2 a$ & $\begin{array}{l}\text { 1. On each of the product type pages (from } \\
\text { the sub-menu: "Housing" and } \\
\text { "Business Area"), a "Virtual Reality } \\
\text { View" button will be created which, } \\
\text { when clicked, opens a new window } \\
\text { displaying the virtual reality product } \\
\text { display . The public can view the } \\
\text { product building form by running the } \\
\text { existing camera view by using the } \\
\text { following keyboard functions: } \\
\text { i. W key, to advance. } \\
\text { ii. D key, to swipe right. } \\
\text { iii. A Button, to swipe left. } \\
\text { iv. S button, to back off. } \\
\text { v. Space Bar, to jump. } \\
\text { vi. Esc + key click anywhere, to exit } \\
\text { vii. Move the mouse to the right, to } \\
\text { viii. Move the mouse to the left, to turn } \\
\text { the camera to the left. }\end{array}$ \\
\hline $3 a$ & $\begin{array}{l}\text { 1. At this time, the company has an } \\
\text { account listing on the property search } \\
\text { site, namely: rumah123.com. } \\
\text { 2. In each listing page, will be displayed a } \\
\text { company website link that can be } \\
\text { clicked by the public to open the } \\
\text { company website. }\end{array}$ \\
\hline $3 b$ & $\begin{array}{l}\text { 1. Each sales executive is required to } \\
\text { have at least } 3 \text { social media accounts } \\
\text { that will be used to share posting links } \\
\text { from each listing page. Share this done } \\
\text { at least } 2 \text { days. } \\
\text { 2. Each sales executive is required to have } \\
1 \text { email account that will be used to } \\
\text { share all linked listings to the entire } \\
\text { database of consumer props. Share this } \\
\text { done at least } 3 \text { days (with bcc to } \\
\text { marketing administration). }\end{array}$ \\
\hline $4 a$ & $\begin{array}{l}\text { 1. On the website, a "Home" menu will be } \\
\text { created which will display: } \\
\text { a. Images that can be switched } \\
\text { automatically to the right (can also } \\
\text { be clicked in the right direction and } \\
\text { towards left), as for image material } \\
\text { to be loaded about: } \\
\text { i. Products sold and / or up-to- } \\
\text { date. } \\
\text { ii. Ongoing promotion } \\
\text { iii. Latest news. } \\
\text { b. Recent News List and Promo } \\
\text { (accompanied by images and short } \\
\text { news content). People can see the } \\
\text { complete news content by clicking } \\
\text { on the news list. A news list view }\end{array}$ \\
\hline
\end{tabular}




\begin{tabular}{|c|c|}
\hline & $\begin{array}{l}\text { will be displayed on four pages on } \\
\text { the homepage, with box drawings } \\
\text { and short news content underneath. } \\
\text { c. List of Articles, which will be } \\
\text { displayed in the form of a list-list } \\
\text { under the News and Promo } \\
\text { columns. To view the contents of } \\
\text { the article in full, people can click } \\
\text { on the list. The list of articles will } \\
\text { include articles on property } \\
\text { information, property developments } \\
\text { and tips on choosing good } \\
\text { properties. }\end{array}$ \\
\hline $4 b$ & $\begin{array}{l}\text { 1. Each sales executive is required to } \\
\text { have at least } 3 \text { social media accounts } \\
\text { that will be used to share post links } \\
\text { from each news page, promo or article. } \\
\text { Share this done at least } 2 \text { days. } \\
\text { 2. Each sales executive is required to have } \\
1 \text { email account that will be used to } \\
\text { share the link to the entire database of } \\
\text { consumer props. This share must be } \\
\text { done every time there is a new promo. } \\
\text { Share news and articles viewed from } \\
\text { the importance of the content of news } \\
\text { and articles (with bcc to marketing } \\
\text { administration). }\end{array}$ \\
\hline
\end{tabular}

\begin{tabular}{|c|l|l|}
\hline 15 & On the website, will be made menu \\
& "Contact Us". This menu will be used \\
by the community to contact the \\
project's sales executive to inquire \\
further information / request to be \\
contacted. This menu can also be used \\
by the community to submit critiques \\
and suggestions. This menu will display \\
a map of the project location (google \\
maps). In this menu there will be \\
several fields, including: \\
a. Name. \\
b. Address. \\
c. Mobile phone number. \\
d. Email. \\
After the community sends a message \\
in the "Contact Us" menu, the message \\
will be sent to Marketing \\
Administration email, which will be \\
sent to the sales executive (as per the \\
order of acceptance)
\end{tabular}

\section{Action}

\section{Use Case Diagram}

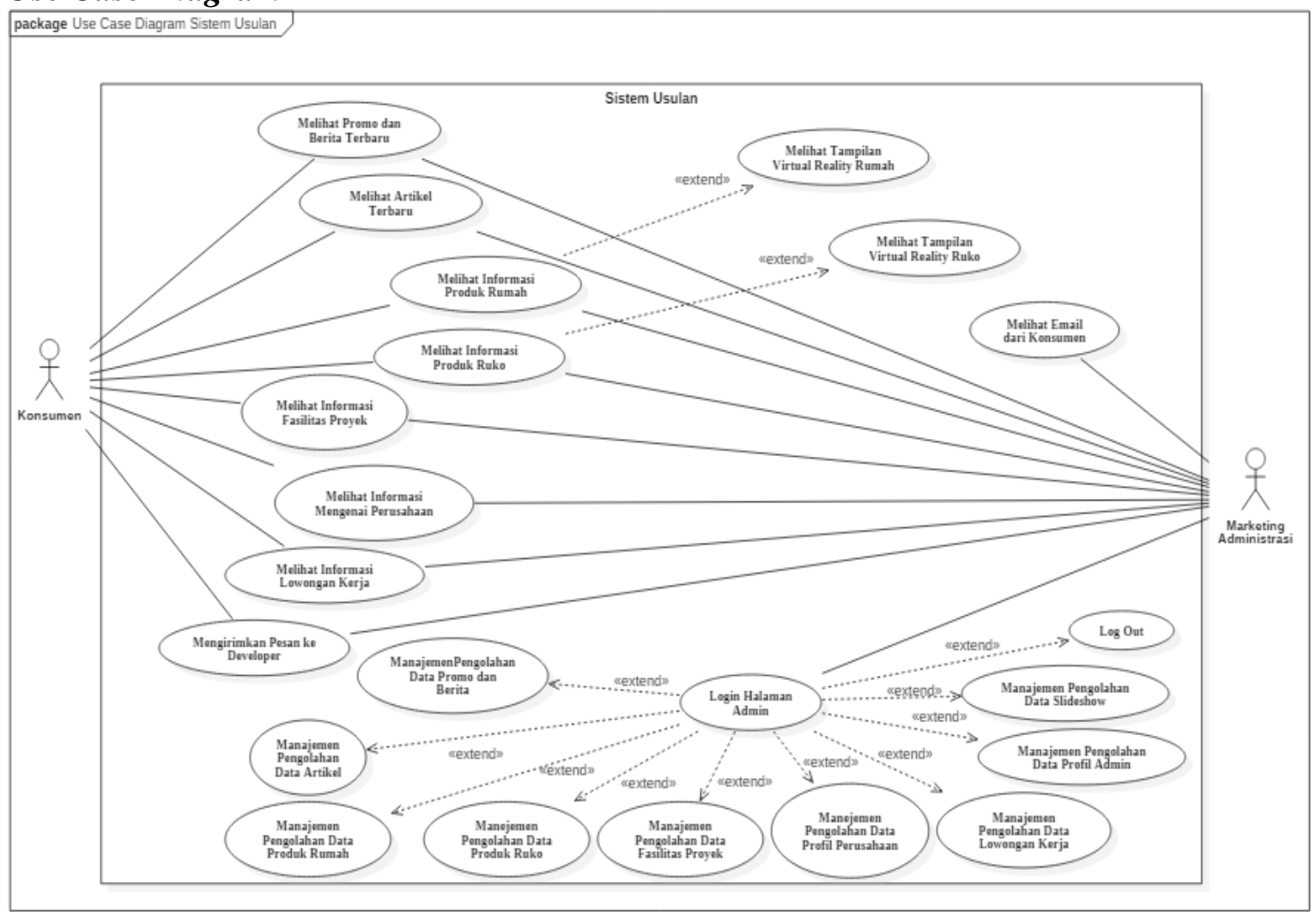

Figure 1 Use Case Diagram 
Activity Diagram:

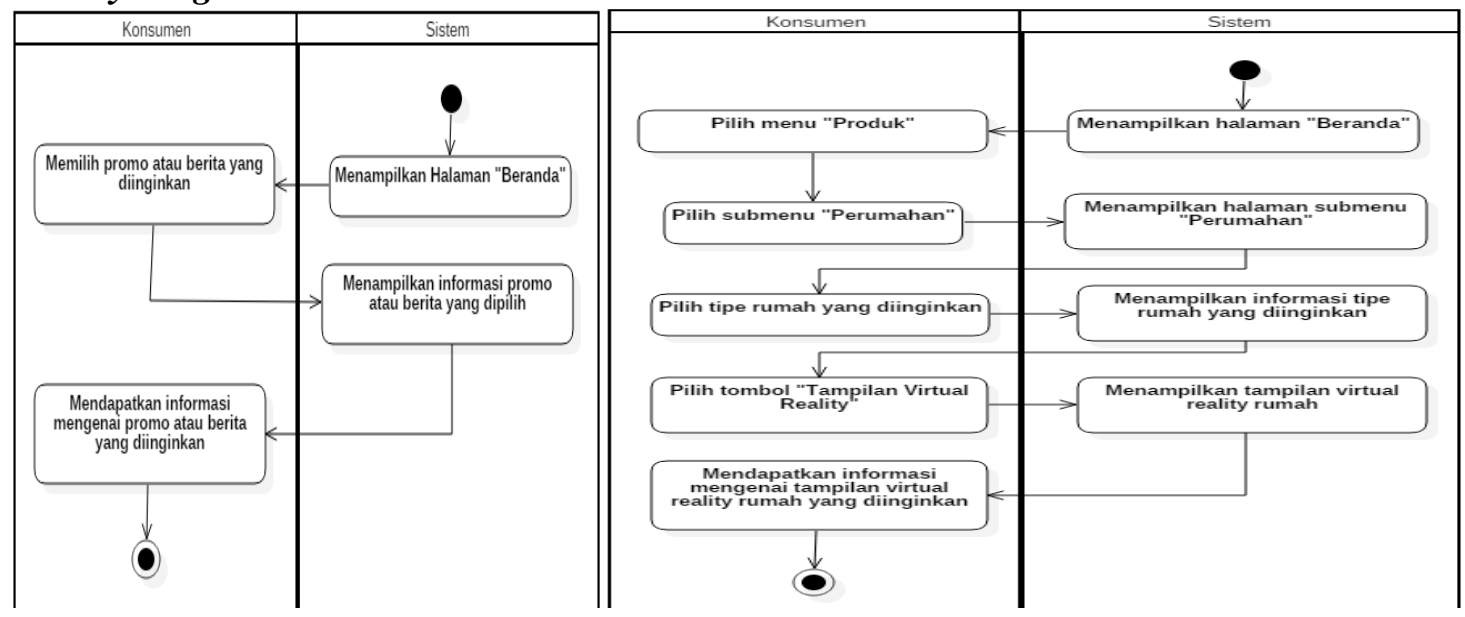

Figure 2 Activity Diagram Show Promo and View Virtual Reality View House

\section{Design Database (Entity Relationship Diagram)}

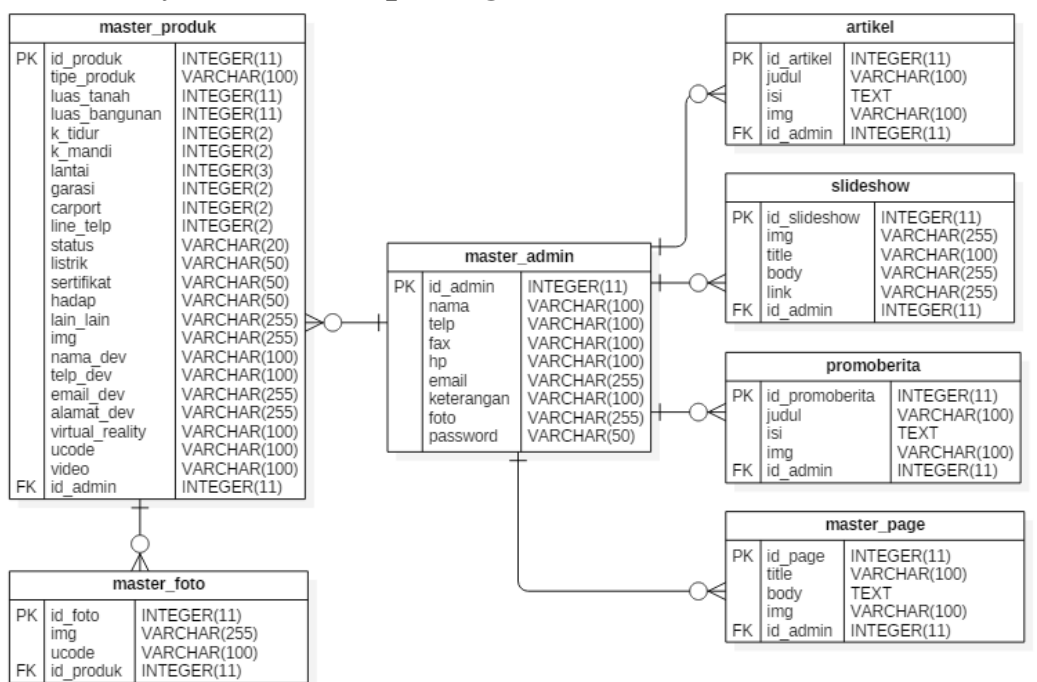

Figure 3 Desain Database (Entity Relationship Diagram)

Design Web

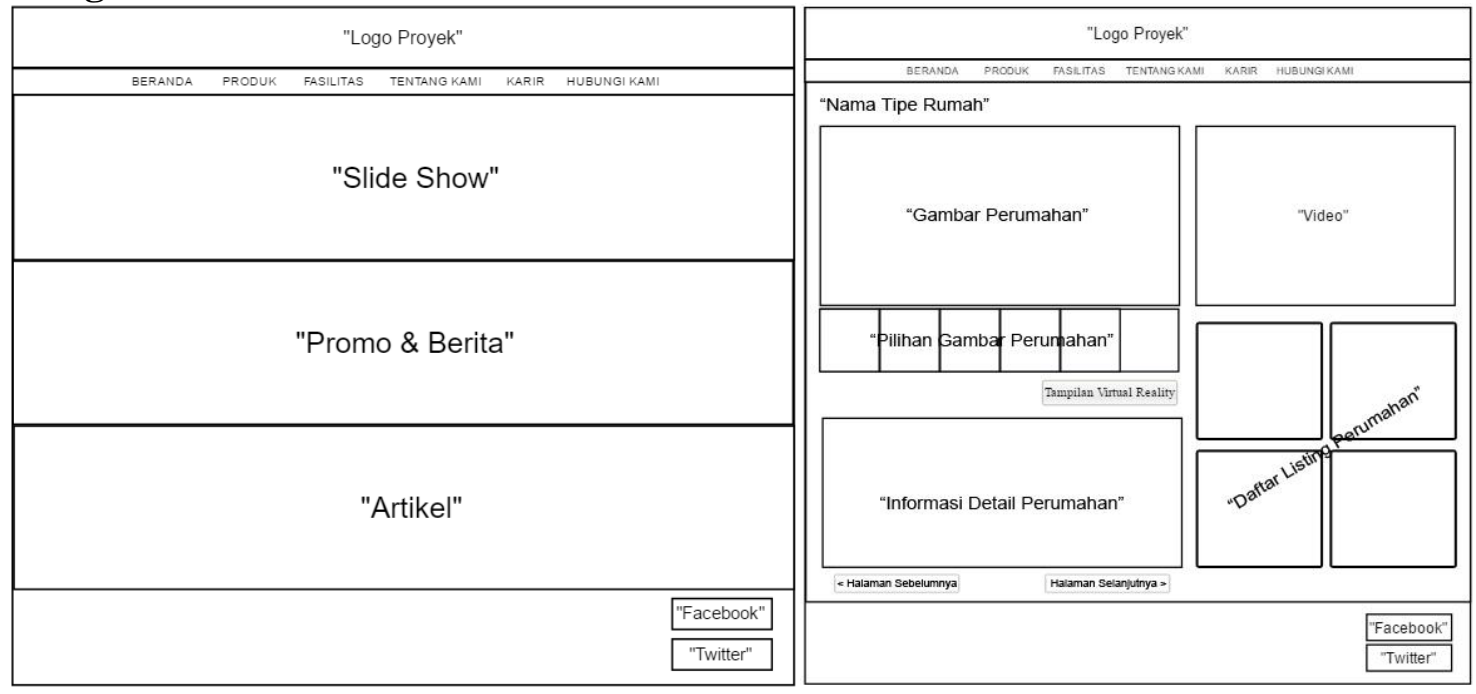

Figure 4 Homepage "Home and Virtual Reality Type Homes" 


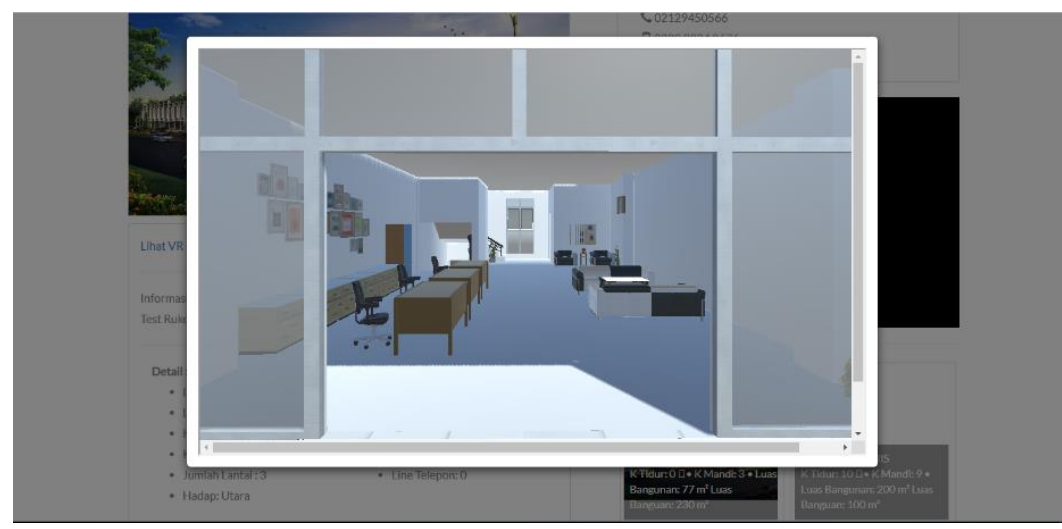

Figure 5 Website Pageviews "Virtual Reality"

\section{Control}

At this stage, the authors will perform 2 (two) control process of application implementation made, that is Black Box Testing and Application Appraisal Survey which will be done by distributing questioner to some respondents. Here is the process:

\section{Black Box Testing}

Figure 8 Hasil Pengujian Black Box

\begin{tabular}{|c|c|c|c|c|c|}
\hline \multirow[t]{2}{*}{$\begin{array}{l}\mathrm{N} \\
\mathrm{O}\end{array}$} & \multirow{2}{*}{$\begin{array}{l}\text { Test } \\
\text { Descrip } \\
\text { tion }\end{array}$} & \multirow[t]{2}{*}{ Test Procedure } & \multirow{2}{*}{$\begin{array}{l}\text { Data } \\
\text { Entry }\end{array}$} & \multicolumn{2}{|c|}{$\begin{array}{c}\text { Evaluasi } \\
\text { Criteria }\end{array}$} \\
\hline & & & & $\mathrm{Y}$ & $\mathrm{N}$ \\
\hline 1 & Home & $\begin{array}{c}\text { Go to Website, } \\
\text { Click Home } \\
\text { Page }\end{array}$ & - & $\sqrt{ }$ & \\
\hline 2 & $\begin{array}{l}\text { Product } \\
- \\
\text { Housin } \\
\text { g }\end{array}$ & $\begin{array}{l}\text { Go to Website, } \\
\text { Click Product, } \\
\text { Click Housing }\end{array}$ & - & $\sqrt{ }$ & \\
\hline 3 & $\begin{array}{l}\text { Product } \\
\text { s - } \\
\text { Busines } \\
\text { s Area }\end{array}$ & $\begin{array}{l}\text { Go to Website, } \\
\text { Click Product, } \\
\text { Business Area }\end{array}$ & - & $\sqrt{ }$ & \\
\hline 4 & $\begin{array}{c}\text { Facilitie } \\
\text { s }\end{array}$ & $\begin{array}{l}\text { Go to Website, } \\
\text { Click Facility, }\end{array}$ & - & $\sqrt{ }$ & \\
\hline 7 & $\begin{array}{l}\text { About } \\
\text { Us }\end{array}$ & $\begin{array}{l}\text { Go to Website, } \\
\text { Click About Us }\end{array}$ & - & $\sqrt{ }$ & \\
\hline 9 & $\begin{array}{l}\text { Contact } \\
\text { Us }\end{array}$ & $\begin{array}{c}\text { Go to Website, } \\
\text { Click Contact } \\
\text { Us }\end{array}$ & - & $\sqrt{ }$ & \\
\hline
\end{tabular}

\section{Application Assessment Questionnaire}

Based on the results of the questionnaire that has been done to 12 respondents and after the calculation of the percentage of each category of assessment, obtained data as follows:
a. Strongly agree
$: 39,4 \%$
b. Agree
$: 52,3 \%$
c. Less Agree
$: 7,2 \%$
d. Disagree
$: 1,1 \%$

Based on these results can be drawn a conclusion that the application made can be well received by the public and prospective consumers as well as get a positive response to the functions contained in the application and has achieved the goal of making this application.

\section{Conclusion}

In accordance with the discussion and evaluation as well as some testing through black box testing and questionnaires that have been given to several respondents and after the analysis and design of marketing strategies using SOSTAC method, it can be taken some conclusions as follows:

1. With this application, can facilitate the public in finding products sold, along with complete product information.

2. This app is a great place to display the latest promos, news and articles that can be seen by the public or potential customers, so as to increase the desire to contact marketing executive.

3. With this application, can help consumers to see the form of building products that will be purchased later, so that consumers have guidelines about the house or shop that will occupy later. This greatly increases consumer confidence in making the decision to make a purchase. 


\section{References}

Abidin, Riswan “Pengertian Virtual Reality dan Perbedaannya Dengan Augmented Reality”, 2015. [Online] Tersedia: https://teknojurnal.com/pengertian-virtual-reality-dan-perbedaanyadengan-augmented-reality/, accessed 30 April 2017

Arief, M. Rudianto. Pemrograman Web Dinamis Menggunakan Php dan Mysql. Yogyakarta: ANDI, 2011.

Arifin, Hasnul. Merakit Sendiri Komputer Tahan Banting Dengan Modal 1 Jutaan. Yogyakarta: Mediakom, 2010.

AS., Ranang, and Hetty D. Agustin. Teknik Foto Virtual Reality Panduan Praktis Dengan Pano Worx. Yogyakarta: Graha Ilmu, 2007.

Azis, M. Farid. 2005. Object Oriented Programming PHP 5. Jakarta: PT. Elex Media Komputindo.

Chaffey, Dave, Fiona Ellis-Chadwick, Richard Mayer, dan Kevin Johnston. Internet marketing: strategy, implementation and practice. Pearson Education, 2009.

Hendrayudi. VB 2008 Untuk Berbagai Keperluan Pemrograman. Jakarta: PT. Elex Media Komputindo, 2009.

Indrajani. Database Design. Jakarta: PT Elex Media Komputindo, 2015.

Manullang, Rio. Mudah Membuat Desain 3D dengan Google SketchUp. Jakarta: PT. Elex Media Komputindo, 2017.

Matakoin, Ella. E-Commerce Pengertian E-Marketing Pemasaran Online dalam Internet. Desember 26 2016. accessed Mei 10, 2017. http://www.matakoin.com/2016/12/pengertiane-marketing-adalah.html.

Nugroho, Adi. Perancangan Dan Implementasi Sistem Basis Data. Yogyakarta: CV. ANDI OFFSET, 2011.

Oktavian, Diar Puji. Menjadi Programmer Jempolan Menggunakan PHP. Yogyakarta: Mediakom, 2009.

Padeli. Cara Mudah Membangun Informasi Dengan Website. Serang: Dinas Pendidikan Provinsi Banten, 2014

Perangin Angin, Frans S. 2012. Scribd. Februari 22. accessed Mei 5, 2017. https://www.scribd.com/doc/82383199/Beberapa-pengertian-perumahan.

Plus, Property. Strategi Membangun Bisnis Developer Property. Jakarta Selatan: Ufuk Press, 2010.

Pranata, Baskara Arya. Mudah Membuat Game dan Potensi Finansialnya dengan Unity 3D. Jakarta: PT. Elex Media Komputindo, 2015.

Pratama, I Putu Agus Eka. E-Commerce, E-Business Dan Mobile Commerce. Bandung: Informatika Bandung, 2015.

—. 2014. Komputer \& Masyarakat. Bandung: Informatika Bandung.

Prisgunanto, Ilham. Komunikasi Pemasaran : Strategi dan Taktik. Bogor: Ghalia Indonesia, 2006

Rahardja, Untung. Siapa Saja Bisa Membuat Website dengan CSS dan HTML. Yogyakarta: Andi, 2009

Sanjaya, Ade. Pengertian Developer Definisi Hak Kewajiban Tanggung Jawab Pelaku Usaha $\begin{array}{llllll}\text { Perumahan. } & \text { Oktober } & 15 & 2015 .\end{array}$ http://www.landasanteori.com/2015/10/pengertian-developer-definisi-hak.html.

Simarmata, Janner. Rekayasa Perangkat Lunak. Yogyakarta: CV. ANDI OFFSET, 2010

Stauer, Jonathan. Unity Virtual Reality Projects. Birmingham: Packt Publishing Ltd, 2015

Sunyoto, Danang. Dasar-Dasar Manajemen Pemasaran . Yogyakarta: CAPS, 2012

Supardi, Yuniar. Semua Bisa Menjadi Programmer Java. Jakarta: PT. Elex Media Komputindo, 2010.

Zaki, Ali. Animasi Karakter dengan Blender dan Unity. Jakarta: PT. Elex Media Komputindo, 2016 


\section{BIOGRAPHY}

Philip Kristy Wijaya - Graduated in Informatics Engineering Study Program, 2017, working at PT. Ligamas Sejahtera Hunian as Marketing Admnistrasi.

Aditiya Hermawan - Graduated from Strata I in 2010 at Informatics Engineering Program, and graduated Strata II (S2) in 2013 at Computer Science. Currently active as a Permanent Lecturer in Informatics Engineering Program, Buddhi Dharma University. 